\title{
Assessment of the perception of quality in mexican municipal sports services
}

\section{Valoración de la percepción de calidad en los servicios deportivos municipales mexicanos}

MORQUECHO-SÁNCHEZ, Raquel†’, SOLIS-GONZALEZ, Jesús”, GONZALEZ-CASTRO, Juan Carlos Arturo’ and ACOSTA-GONZALEZ, Ariana Linette'

'Universidad Autónoma de Nuevo León, Faculty of Sports Organization, Mexico.

"Universidad Autónoma de Nuevo León, Faculty of Public Accounting and Administration, Mexico.

ID 1 ${ }^{\text {st }}$ Author: Raquel, Morquecho-Sánchez / ORC ID: 0000-0003-4993-8027

ID $1^{\text {st }}$ Co-author: Jesús, Solis-Gonzalez / ORC ID: 0000-0002-9551-1051

ID $2^{\text {nd }}$ Co-author: Juan Carlos Arturo, Gonzalez-Castro / ORC ID: 0000-002-2610-3636

ID $3^{\text {rd }}$ Co-author: Ariana Linette, Acosta-Gonzalez / CVU CONACYT ID: 887928

DOI: $10.35429 / E J R P .2021 .13 .7 .25 .28$

Received July 25, 2021; Accepted December 30, 2021

\begin{abstract}
The objective of the present investigation was to assess the perception quality of municipal sports services of the city of Allende, Nuevo León, Mexico. For the analysis of the data the statistical software SPSS v.24 was used. The instrument used was SERVQUAL, adapted to the Mexican sports context, which consists of 22 items grouped into 5 dimensions (tangible, empathy, reliability, responsiveness and safety). The sample of this study was 100 subjects, in a range of 16 to 60 years, of which 57 (51.6\%) belong to the male gender and $43(48.4 \%)$ to the female gender. The descriptive and correlation analyzes of the sample were carried out. Among the results obtained, the study presents acceptable quality values for said municipal complex. In conclusion, the evaluation, monitoring of the objectives and indicators of the municipal sports services are of vital importance to perform an adequate follow-up of the expectations, perception and satisfaction of its users, which will make municipal sports management more efficient.
\end{abstract}

Perception, Sports services, Quality, Municipalities, SERVQUAL

\begin{abstract}
Resumen
El objetivo de la presente investigación fue valorar la percepción de la calidad de los servicios deportivos municipales en Allende, Nuevo León, México. Para el análisis de los datos se utilizó el software estadístico SPSS v.24. El instrumento utilizado fue el SERVQUAL, adaptado al contexto deportivo mexicano, el cual consiste en 22 ítems agrupados en 5 dimensiones (tangibles, empatía, fiabilidad, capacidad de respuesta y seguridad). La muestra de este estudio fue de 100 sujetos, en un rango de 16 a 60 años, de los cuáles 57 (51.6\%) pertenecen al género masculino y $43(48.4 \%)$ al género femenino. Se realizaron los análisis descriptivos y de correlación de la muestra. Entre los resultados obtenidos, el estudio presenta valores de calidad aceptables para dicho complejo municipal. Como conclusión, la evaluación y el seguimiento de los objetivos e indicadores de los servicios deportivos municipales son de vital importancia para realizar un adecuado seguimiento de las expectativas, percepción y satisfacción de sus usuarios, lo cual hará más eficaz la gestión deportiva municipal.
\end{abstract}

Percepción, Servicios deportivos, Calidad, Municipios, SERVQUAL

Citation: MORQUECHO-SÁNCHEZ, Raquel, SOLIS-GONZALEZ, Jesús, GONZALEZ-CASTRO, Juan Carlos Arturo and ACOSTA-GONZALEZ, Ariana Linette. Assessment of the perception of quality in mexican municipal sports services. ECORFAN Journal-Republic of Peru. 2021. 7-13:25-28.

\footnotetext{
* Correspondence to Author (E-mail: raquel.morquechosn@uanl.edu.mx)

$\dagger$ Researcher contributing first author.
} 


\section{Introduction}

The sport and its management have been acquired greater importance, more and more users demand sport activities in public and private places. In this way, there is a great concern to improve the provision of municipal sports services, with leads service organizations to a great degree of demand.

In this sense, municipal sports services are obliged to strategies based on improving user satisfaction, incorporating plans that help improve the quality of their services. Consequently, we find new management models, new strategies, where research has gained importance to find the right formula to achieve effectiveness and efficiency, the management of services and all the element involved towards quality in this management provision, since the quality of the service not only refers to an internal experience of each persona, but to the assessment of attributes external to the service (Sánchez-Hernández et al., 2009).

Nowadays the request and also the expectations of users regarding public sports services have increased, and they aren't longer satisfied with access to practice and a space to develop it, but they demand a high variety of physical activity programs, qualified professionals, adequate facilities as of image, dimensions, hygiene, safety, etc. and the administrations have the obligations to confront all these demands and accomplish with the expectations through sports services that reach satisfy. In this sense, the municipal sports services must be concerned about the quality of the services offered, for these reasons the objective is to assess the perceived quality of municipal sports services, in the Bicentenario Park, located in Allende, Nuevo León.

\section{Methodology}

\section{Study design}

The present study id non-experimental, crosssectional, quantitative and with a descriptivecorrelational scope.

\section{Population}

The population of this research is made up of users who carry out sports and recreation activities within the Bicentenario Park, in different activities offered by the municipality such as soccer, basketball, volleyball, table tennis, fronton, gym and swimming, among others during the year 2019.

\section{Sample}

The selection of the participants was through a non-probabilistic convenience, with the participation of 100 subjects, which 57 (51.6\%) belong to the male gender and $43(48.4 \%)$ to the female gender, in an age range between 16 as the minimum age and 60 as the maximum age.

\section{Statistical analysis}

The data analysis is descriptive in nature; its objective is to summarize the information by means of the elaboration of explanatory graphs, as well as the inclusion o frequency tables. The data obtained were processed using the SPSS version 24 statistical package.

For the treatment of the data, first, descriptive analyses of frequency and central tendency, reliability analysis of the scales using Cronbach's alpha were performed to determine the reliability of the instrument. Subsequently, correlation analyses will be carried out to observe the relationship between the study variables.

\section{Instrument}

The instrument used was the SERVQUAL, which is a scale for measuring the quality of service, consisting of a scale of 22 items on the expectations and perceptions of users, referring to a category of service, and the 22 items are grouped into 5 dimensions: reliability, responsiveness, safety, empathy, and tangible elements.

\section{Procedure}

Authorization was requested from the Director of Sports of the municipality of Allende to apply the questionnaires. 
The surveyors applied the instrument once the physical activity session was over, the instructions on how to answer the questionnaire were explained to them and they were informed that the questionnaire was confidential; it is worth mentioning that the surveyor was always present during its application.

\section{Results}

\section{International consistency analysis}

International consistency was calculated using Cronbach's alpha index, in relation to the resulting factors tant make up the instrument. The reliability analysis revealed good internal consistency, showing values in this case above 0.70 for each factor (Cronbach, 1951), between a range of 0.89 and 0.94 (see Table 1). The reliability of each of the scales that make up the instrument was tested, determining the Cronbach's alpha coefficient. The value obtained was found to be within the range established by George and Malley (2003) and Nunnally (1976) to accept internal consistency.

\section{Alfa de Cronbach Expectations Perceptions}

\begin{tabular}{l|l|}
0.893 & 0.948 \\
\hline
\end{tabular}

Table 1 Cronbach alpha expectations and perceptions

\section{Descriptive analysis}

The total sample consisted of 100 subjects, of whom $57(51.6 \%)$ were male and 43 (78.4\%) females, with an age range between 16 and 60 years (see figure 1).

$48.7 \%$

$49 \% 1 \%$

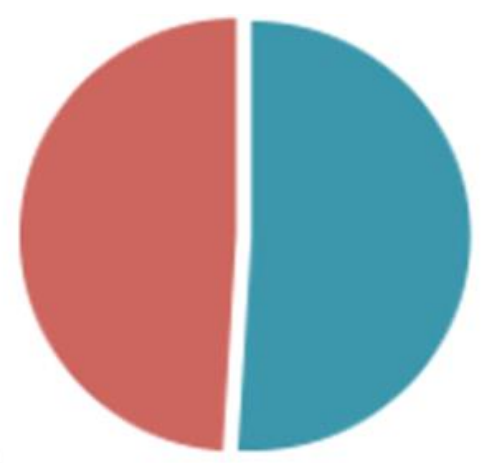

$$
\text { - Man Woman }
$$

Figure 1 Distribution of the sample by gender

Graphic 1 shows that $45 \%$ of the users feel safe in the Bicentenario Park facilities, so we should consider improving this element in the organization.

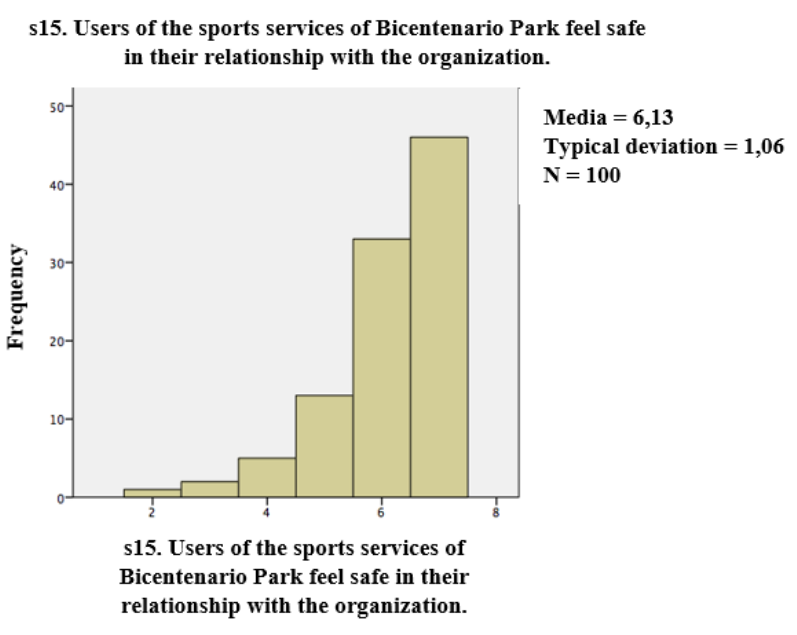

Graphic 1 Safety in relation to the sports facility

In table 2, communication and interaction with the coach is presented, composed by item 10 , we can observe tant we obtain a frequency value between $221 \%$ and $38 \%$ of users who agree to strongly agree, showing as a result that the user considers communication and interaction with the coach as a fundamental part, presenting satisfactory in the municipal sport facilities.

\begin{tabular}{|l|l|r|r|}
\hline \multicolumn{1}{|c}{} & Frequency & Porcentage \\
\hline \multirow{7}{*}{ Valid } & Strongly disagree & 2 & 2,0 \\
\cline { 2 - 4 } & Not at all agree & 2 & 2,0 \\
\cline { 2 - 4 } & Somewhat agree & 7 & 7,0 \\
\cline { 2 - 4 } & Agreement & 21 & 21,0 \\
\cline { 2 - 4 } & Agree & 30 & 30,0 \\
\cline { 2 - 4 } & Strongly agree & 38 & 38,0 \\
\cline { 2 - 4 } & Total & 100 & 100,0 \\
\hline
\end{tabular}

Table 2 Communication with users

Table 3 shows the availability of the coaches in item 15 . The most significant results show that $49 \%$ of the users strongly agree with the availability of help and problem solving by the trainers, while the rest are divided between different opinion, so that new and different mechanisms of internal communication with the users should be considered, as well as effectively communicating the follow-up of suggestions or complaints, with the objective of finding a continuous improvement.

\begin{tabular}{|c|l|r|r|}
\hline \multicolumn{1}{|c|}{} & \multicolumn{1}{|c|}{ Frequency } & \multicolumn{2}{c|}{ Porcentage } \\
\hline \multirow{5}{*}{ Valid } & Little Agree & 3 & 3,0 \\
\cline { 2 - 4 } & $\begin{array}{l}\text { Somewhat } \\
\text { agree }\end{array}$ & 3 & 3,0 \\
\cline { 2 - 4 } & Agreement & 15 & 15,0 \\
\cline { 2 - 4 } & Agree & 30 & 30,0 \\
\cline { 2 - 4 } & Strongly agree & 49 & 49,0 \\
\cline { 2 - 4 } & Total & 100 & 100,0 \\
\hline
\end{tabular}

Table 3 Availability of trainers to assist users 


\section{Conclusion}

The evaluation of perceptions has been the line of research of different authors, who have designed instruments to measure the perceptions of users regarding the quality of serviced such as (Calabuig et al., 2008; Nuviala et al., 2008).

We agree that service should be continuously monitored (Morales-Sánchez, 2003), which is essential to ensure the processes of loyalty and maintenance of quality standards that allow comparison with other organizations or with the same organization in quality management processes (Clabuig et al., 2010; Morales-Sánchez, 2003).

Although quality evaluation is currently of great importance, its application to the field of sports management and specifically to the evaluation of municipal sports services is still scarce, especially in Mexico.

It is concluded that the services provided by the Bicentenario Park meet the expectations and perceptions of its users, since the results are significant. As future research, total quality can be evaluated, considering the internal and external clients of municipal sports organizations.

\section{References}

Calabuig, F. M., Gómez, J. J. M., \& Hervàs, J. C. (2010). Eventqual: una medida de la calidad percibida por los espectadores de eventos deportivos. Retos: nuevas tendencias en educación física, deporte y recreación, (18), 6670.

Calabuig, F. M., Pardo, I. Q., \& Gómez, J. M. (2008). La calidad percibida de los servicios deportivos: diferencias según instalación, género, edad y tipo de usuario en servicios náuticos. RICYDE. Revista Internacional de Ciencias del Deporte. doi: 10.5232/ricyde, 4(10), 25-43.

Gallardo, L. y Jiménez, A. (2004). La gestión de los servicios deportivos municipales. Barcelona: Inde.
Nuviala, A. N., Fajardo, J. A. T., Llopis, J. I., \& Miguel, D. F. (2008). Creación, diseño, validación y puesta en práctica de un instrumento de medición de la satisfacción de usuarios de organizaciones que prestan servicios deportivos. Retos: nuevas tendencias en educación física, deporte y recreación, (14), 1016.

Morales Sánchez, V. (2003). Evaluación psicosocial de la calidad en servicios municipales deportivos: aportaciones desde el análisis de variabilidad. Málaga: SPICUM.

Morales Sánchez, V. y Correal, J. (2003). La Calidad en la gestión de los servicios deportivos. En A. Hernández Mendo (Coord.), Psicología del Deporte (Vol. III) - Aplicaciones 2 (81-101). Buenos Aires: Efdeportes.com.

Morales Sánchez, V., Hernández Mendo, A. y Blanco, Á. (2009). Evaluación de la calidad en organizaciones deportivas: adaptación del modelo SERVQUAL. Revista de Psicología del Deporte, 18(2), 137-150.

Sánchez-Hernández, R. M., Martínez-Tur, V., González-Morales, M. G., Ramos, J. y Peiró, J. M. (2009). Un análisis transnivel de las relaciones de la calidad de servicio y la confirmación de expectativas con la satisfacción de los usuarios. Psicothema, 21(3), 421-426. 